\title{
Determination of Thermostability Degree of Lycopene in Watermelon (Citrullus lanatus)
}

\author{
Bohuslava Tremlova (D), Hana Koudelkova Mikulaskova *, Tomas Pencak, Karolina Tesikova, Simona Dordevic (D) \\ and Dani Dordevic (D)
}

Citation: Tremlova, B.; Mikulaskova, H.K.; Pencak, T.; Tesikova, K.; Dordevic, S.; Dordevic, D. Determination of Thermostability Degree of Lycopene in Watermelon (Citrullus lanatus). Separations 2021, 8, 220. https://doi.org/10.3390/ separations 8110220

Academic Editor: Ernesto Reverchon

Received: 26 October 2021

Accepted: 12 November 2021

Published: 17 November 2021

Publisher's Note: MDPI stays neutral with regard to jurisdictional claims in published maps and institutional affiliations.

Copyright: (c) 2021 by the authors. Licensee MDPI, Basel, Switzerland. This article is an open access article distributed under the terms and conditions of the Creative Commons Attribution (CC BY) license (https:// creativecommons.org/licenses/by/ $4.0 /)$.
Department of Plant Origin Food Sciences, Faculty of Veterinary Hygiene and Ecology, University of Veterinary Sciences Brno, Palackeho tr. 1946/1, 61242 Brno, Czech Republic; tremlovab@vfu.cz (B.T.); h21263@vfu.cz (T.P.); tesikovak@vfu.cz (K.T.); dordevics@vfu.cz (S.D.); dordevicd@vfu.cz (D.D.)

* Correspondence: koudelkovamih@vfu.cz

\begin{abstract}
The aim of the work was to determine the degree of watermelon (Citrullus lanatus) thermostability according to the content of the present bioactive compounds and antioxidant properties. The watermelon samples were exposed to the following temperatures/time regimes: 40, 70, and $100{ }^{\circ} \mathrm{C} ; 2,5$, and $15 \mathrm{~min}$. The sample characteristics were monitored by spectrophotometric and chromatographic methods. Statistically significant $(p<0.05)$ differences were observed between the heat-treated samples compared to the heat-untreated control sample; differences were found almost between all samples. The total polyphenol content increased in all heat-treated samples. The highest total polyphenol content was observed among samples treated at $40{ }^{\circ} \mathrm{C}$ for $15 \mathrm{~min}(1.38 \pm 0.01 \mathrm{mg} / \mathrm{g})$. Lycopene content (measured by spectrophotometer) also increased in the same samples exposed to $40{ }^{\circ} \mathrm{C}$ for $5 \mathrm{~min}(65.45 \pm 0.20 \mathrm{mg} / \mathrm{kg})$, though higher temperatures $\left(70\right.$ and $\left.100{ }^{\circ} \mathrm{C}\right)$ resulted in lycopene degradation. Chromatographic method (measured by high-pressure liquid chromatography) showed lycopene degradation after each heating treatment. Not unambiguously, results and observations were not found in antioxidant activity due to oscillations in measured bioactive compounds. The obtained results emphasize processes in heat-treated watermelon, and they can be useful in the production of different products where this food commodity can be included.
\end{abstract}

Keywords: watermelon; Citrullus lanatus; lycopene; carotenoids; antioxidant activity; polyphenols; organic acids

\section{Introduction}

Phytonutrients are plant-derived substances that play a key role in maintaining human health, especially in disease prevention. These substances based on phytochemicals from fruit and vegetables have recently become increasingly popular due to consumer awareness of their health benefits. This broad group of natural substances includes phenolic compounds and carotenoids, showing considerable antioxidant activity [1].

Due to various forms of stress on the human body, there is an increased production of reactive oxygen species (ROS) that are highly toxic and cause damage to proteins, lipids, carbohydrates, and DNA, leading to oxidative stress [2], in particular superoxide, hydrogen peroxide, and hydroxyl radicals that are usually detoxified by intracellular enzymes such as glutathione, superoxide dismutase, and catalase [3]. Oxidative stress damages tissues and leads to many diseases. Oppositely, antioxidants neutralize these reactive oxygen species and prevent diseases [4].

Among carotenoids, attention has been paid mainly to $\alpha$ - and $\beta$-carotene due to their provitamin properties, but lycopene has proven over time to be a key phytochemical for its significant effects on human health. In watermelons, the lycopene content represents approximately $70-90 \%$ of all carotenoids and acts as an important phytochemical compound [5]. 
The main sources of lycopene in human diet are mainly tomatoes and tomato products, pink guava, and pink grapefruit. Compared to tomatoes, watermelon contains higher amounts of lycopene and its bioavailability to the human body is at the same level [6,7].

Lycopene is an acyclic polyunsaturated open-chain organic compound that contains 13 double bonds, of which 11 double bonds are conjugated and linearly arranged. Therefore, lycopene is longer than any other carotenoid that gives some fruit a reddish appearance [8]. It is a bioactive compound that is widely recognized for its nutritional and pharmaceutical application. In vivo clinical studies have shown that lycopene is effective in reducing oxidative stress and inhibiting the growth of cancer cells, such as prostate, colon, breast, and liver tumors [9]. Lycopene can be ranked among the most important and most used carotenoids with a high antioxidant activity that may play an important role in prostate cancer prevention [10]. Previously, tomatoes and products thereof were considered to be the main source of lycopene, but watermelon is also an important source of lycopene [7].

The chemical composition of lycopene allows its absorption in body tissues, but due to the absence of the $\beta$-ionone ring it lacks the provitamin activity of vitamin A. Nevertheless, lycopene is an effective antioxidant and its ability to scavenge free hydroxyl radicals is higher than $\beta$-carotene [1].

Studies showed that industrially processed tomato products are a better source of carotenoids compared to raw tomatoes. It may be related to the better extractability of lycopene after heat treatment or mechanical homogenization [11].

The aim of the study was to monitor changes in bioactive compounds content and antioxidant stability in watermelon (Citrullus lanatus) under different temperature regimes. The novelty of the study can be overseen through the gained results that have never been obtained in this way in previous studies and published in relevant databases. These findings will certainly be helpful for the production and management of food commodities where the main ingredient is watermelon or where watermelon serves as the fortification element of different food commodities.

\section{Materials and Methods}

In the present study, samples of a watermelon originating from Spain were purchased in the Billa market network. The watermelon was divided into 10 sample groups, where sample number 1 was a control sample that was not heat-treated. Samples number 2 to 10 were exposed to temperatures of 40,70 , and $100{ }^{\circ} \mathrm{C}$ for 2 to $15 \mathrm{~min}$ in a laboratory oven. The temperature values and the time of their exposure are shown in Table 1. All analyses were done at least in triplicates.

Table 1. Overview of Samples.

\begin{tabular}{ccc}
\hline Sample Number & Temperature $\left({ }^{\circ} \mathbf{C}\right)$ & Exposition Duration (Min) \\
\hline 1 & - & - \\
2 & 40 & 2 \\
3 & 40 & 5 \\
4 & 40 & 15 \\
5 & 70 & 2 \\
6 & 70 & 5 \\
7 & 70 & 15 \\
8 & 100 & 2 \\
9 & 100 & 5 \\
10 & 100 & 15 \\
\hline
\end{tabular}

\subsection{Determination of Antioxidant Capacity by the ABTS Method}

One of the basic and most widely used methods for determining the total antioxidant capacity is the ABTS method, which tests the ability of a sample to quench the ABTS cation-radical $\bullet+\left(2,2^{\prime}\right.$-azinobis (3-ethyl-2,3-dihydrobenzothiazole-6-sulfonate)). In the observed sample, the quenching of the ABTS $\bullet+$ radical by antioxidants which act as 
hydrogen donors, is monitored spectrophotometrically based on changes in the absorption spectrum of ABTS • + [12].

The sample was weighed $(0.1 \mathrm{~g})$ into a dark tube and $20 \mathrm{~mL}$ of ethanol was added, homogenized with the Homogenizer Witeg Germani, which was used to extract the sample for $30 \mathrm{~min}$. Prior to measurement, a reaction mixture was formed by mixing $10 \mathrm{~mL}$ of a $0.007 \mathrm{M}$ solution of ABTS 2,2'-azinobis (3-ethyl-2,3-dihydrobenzothiazole-6-sulfonate) with $10 \mathrm{~mL}$ of a $0.00245 \mathrm{M}$ solution of potassium persulfate and stored in the dark for 12 up to $16 \mathrm{~h}$. Before the actual measurement of the samples, $1980 \mu \mathrm{L}$ of the ABTS reaction mixture and $20 \mu \mathrm{L}$ of the prepared extract were used. The samples thus prepared were incubated for $5 \mathrm{~min}$ in the dark, and then the absorbance at a wavelength of $735 \mathrm{~nm}$ was measured using CECIL CE 7210 spectrophotometer (Cecil instruments, CE7210 DIET-QUEST, Cambridge, UK) [13].

The results were calculated according to the following formula:

$$
\text { ABTS }(\%)=\left[\left(\mathrm{A}_{\mathrm{ABTS}}-\mathrm{A}_{\text {sample }}\right) / \mathrm{A}_{\mathrm{ABTS}}\right] \times 100
$$

\subsection{Determination of Antioxidant Activity by the NOS (Nitric Oxide Scavenging) Method}

To prepare the samples, $0.1 \mathrm{~g}$ of the sample and $20 \mathrm{~mL}$ of ethanol were weighed, then the extracts were extracted in an ultrasonic water bath for $30 \mathrm{~min}$ and filtered. Next, a reference solution was prepared with $2 \mathrm{~mL}$ of ethanol and $2 \mathrm{~mL}$ of nitroprusside solution ( $10 \mathrm{mmol} / \mathrm{L}$ sodium nitroprusside dihydrate). A sample was prepared by mixing $2 \mathrm{~mL}$ of nitroprusside solution and $2 \mathrm{~mL}$ of sample extract, which was then incubated for $150 \mathrm{~min}$ at $25^{\circ} \mathrm{C}$. After incubation, $2 \mathrm{~mL}$ of incubated sample and $2 \mathrm{~mL}$ of $5 \%$ sulfanilamide solution were mixed, followed by incubation for $5 \mathrm{~min}$ at $25^{\circ} \mathrm{C}$. Finally, $2 \mathrm{~mL}$ of Nedde solution ( $0.2 \%$ naphthylethylenediamine dihydrochloride) was added to the incubated samples, which was again incubated at $25^{\circ} \mathrm{C}$ for $30 \mathrm{~min}$. Absorbance was measured at $540 \mathrm{~nm}$. Prior to measurement, the spectrophotometer was zeroed on phosphate buffer (sodium dihydrogen phosphate monohydrate and disodium hydrogen phosphate heptahydrate) [14]. formula:

The percentage of nitrite radical scavenging activity was calculated according to the

$$
\text { Scavenged nitric oxide }(\%)=\left[\left(\mathrm{A}_{\text {control }}-\mathrm{A}_{\text {test }}\right) / \mathrm{A}_{\text {control }}\right] \times 100
$$

where $A_{b s c o n t r o l}$ represents the absorbance of the control sample and $A_{b s t e s t}$ represents the absorbance of the measured samples.

\subsection{Determination of Antioxidant Activity by the FRAP (Ferric Reducing Antioxidant Potential) Method}

The FRAP (Ferric Reducing Antioxidant Potential) method is based on the principle of a redox reaction, in which the antioxidants present in the sample reduce the $\mathrm{Fe}^{3+}-2,4,6$-tri(2-pyridyl)-1,3,5-triazine complex $\left(\mathrm{Fe}^{3+}-\mathrm{TPTZ}\right)$. An increase in absorbance at $593 \mathrm{~nm}$, which corresponds to the amount of $\mathrm{Fe}^{3+}-\mathrm{TPTZ}$ complex, is a measure of the antioxidant activity of the sample [12].

$0.1 \mathrm{~g}$ of the homogenized sample was weighed and extracted in $20 \mathrm{~mL}$ of $75 \%$ methanol. Extraction in an ultrasonic bath was followed by filtration, after which $180 \mu \mathrm{L}$ of the filtered extract with the addition of $300 \mu \mathrm{L}$ of distilled water was incubated with $3.6 \mathrm{~mL}$ of working solution (acetate buffer $+\mathrm{TPTZ}+\mathrm{FeCl}_{3} \times 6 \mathrm{H}_{2} \mathrm{O}$ in a ratio of 10:1:1) for 8 min in the dark. The absorbance was then measured spectrophotometrically at a wavelength of $593 \mathrm{~nm}$ against a blank. The blank was prepared by mixing $960 \mu \mathrm{L}$ of distilled water and $7.2 \mathrm{~mL}$ of working solution followed by incubation in the dark for $8 \mathrm{~min}$. Results were expressed in $\mathrm{mg} / \mathrm{mL}$ of Trolox, which was used as a standard.

\subsection{Determination of Total Polyphenols Content}

Samples were prepared by mixing $1 \mathrm{~g}$ of the sample with $10 \mathrm{~mL}$ of distilled water, the resulting extract was then filtered, $1 \mathrm{~mL}$ of the filtered extract was mixed with $5 \mathrm{~mL}$ of $10 \%$ Folin-Ciocalteu solution and $4 \mathrm{~mL}$ of $\mathrm{Na}_{2} \mathrm{CO}_{3}(75 \mathrm{~g} / \mathrm{L})$. The sample thus prepared 
was incubated for $30 \mathrm{~min}$ in the dark. After incubation, the sample was measured at a wavelength of $765 \mathrm{~nm}$. The results were expressed in $\mathrm{mg} \cdot \mathrm{mL}^{-1}$ equivalent of gallic acid, which was used to generate a calibration curve [15].

The polyphenols content was calculated according to the formula:

$$
\mathrm{c}(\mathrm{mg} / \mathrm{g})=\mathrm{x} / 3.0959 \times 10
$$

\subsection{Determination of Lycopene Spectrophotometrically}

After weighing the samples and adding the HAE solvent (hexane, acetone, and ethanol in a ratio of 2:1:1), the lycopene is extracted for 15 to $30 \mathrm{~min}$. After extraction of lycopene, water $(15 \mathrm{~mL}$ per $100 \mathrm{~mL}$ of solvent) is added to the solution, whereby phase separation occurs. All extracted lycopene is in the upper capron phase after separation and can be quantified spectrophotometrically at $444 \mathrm{~nm}$ and $503 \mathrm{~nm}$, the spectrophotometer was zeroed on HAE [16].

The lycopene content was calculated using the following formula:

$$
\mathrm{c}(\mathrm{mg} / \mathrm{kg})=(\mathrm{A} / 172.00) \times 0.55 \mathrm{~V} \times 537 \times 1 / \mathrm{W} \times 10^{-6} \approx 1.717 \mathrm{~A} \times \mathrm{V} / \mathrm{W}
$$

The more accurate lycopene content without $\beta$-carotene interference was calculated using the formula below:

$$
\mathrm{c}(\mathrm{mg} / \mathrm{kg})=\left(6.95 \mathrm{~A}_{5} 503-1.59 \mathrm{~A}_{4} 444\right) \times 0.55 \times 537 \mathrm{~V} / \mathrm{W}
$$

\subsection{Determination of Lycopene by the HPLC Method}

An extraction mixture of diethyl ether and hexane in a ratio of 1:1 was added to the sample. The resulting solution was then extracted for $10 \mathrm{~min}$. After evaporation of the solvents on a vacuum rotary evaporator at $40^{\circ} \mathrm{C}$, the sample was subsequently determined by means of Agilent 1260 Infinity high performance liquid chromatography system (Agilent, Santa Clara, CA, USA). Mobile phase ANC (acetonitrile): DCM (dichloromethane), isocratic elution, $10 \mu \mathrm{L}$ injection, $1 \mathrm{~mL} / \mathrm{min}$ inflow, at $22{ }^{\circ} \mathrm{C}$ for $30 \mathrm{~min}$. Detection was performed by DAD (diode array detector) (at $\lambda=470 \mathrm{~nm}$ ), using Agilent ChemStation software (Agilent, Santa Clara, CA, USA, revision: B.04.02) and high-pressure liquid chromatography (producer: Agilent, Santa Clara, CA, USA). The method was modified in compliance with the study by Anthon and Barrett (2007) [16].

\subsection{Determination of Organic Acids by HPLC}

For the determination of organic acids, the samples were homogenized and then extracted for $30 \mathrm{~min}$ at room temperature and then centrifuged at $3000 \mathrm{rpm}$ for $20 \mathrm{~min}$. The extracted sample was filtered through $0.45 \mu \mathrm{m}$ cellulose filter and used for the determination $4 \mathrm{mM}$ sulfuric acid was used as the mobile phase $(20 \mu \mathrm{L}$ injection, $0.6 \mathrm{~mL} / \mathrm{min}$ flow rate, at a temperature of $65^{\circ} \mathrm{C}$ for $30 \mathrm{~min}$ ). Detection was performed by a UV detector at wavelength of $210 \mathrm{~nm}$, using ChemStation software and high-pressure liquid chromatography (producer: Agilent, Santa Clara, CA, USA). A modified method was used in the test, according to the study of Akagić et al. (2019) [17].

\subsection{Statistical Evaluation of Results}

The measured absorbances obtained by spectrophotometric measurements were statistically evaluated using the IBM SPSS Statistics Subscription program (SPSS Statistics 28.0.1, IBM, Chicago, IL, USA) by one-way ANOVA, where the homogeneity of the variances was determined based on the results of the Levene's test. If the Levene's test value was $p<0.05$, the Games-Howell test was used, and if the Levene's test value was $p>0.05$, the Tukey test was applied. The overall overview of differences between the samples, principal component analysis (PCA), with varimax rotation, was used. The results of the laboratory analyses were reported as the mean \pm standard deviation. 


\section{Results and Discussion}

In water and aqueous media, lycopene tends to precipitate as crystals, resulting in reduced absorption in human body. In nature, lycopene can occur in the trans or cis forms; $95 \%$ of lycopene occurring in the more stable trans form. In human serum, lycopene is predominantly present in the cis form: more than $50 \%$ due to the better absorption of the cis form in human body. Isomerization from the more stable trans- form to the less stable mono- or poly-cis form can occur from heat, light, or chemical reactions. Therefore, human body is better able to absorb and use lycopene from foods that have been heat-treated in the form of juices, sauces, pastes or canned food [8]. However, only about $10-30 \%$ of the total amount of lycopene consumed from food is absorbed. In developed countries, the amount of lycopene ingested is approximately $5-7 \mathrm{mg}$ per day [18].

Due to the high water activity that ranges from 0.97 to 0.99 and high $\mathrm{pH}$ (5.2-6.7), watermelons belong among sensitive foods for the presence of pathogenic microorganisms, specifically Gram-positive bacteria. To prolong shelf life and increase use, watermelon juice is processed by various methods that can cause the loss of nutrients and phytochemicals. In the production of fruit juices, the most used method is the short-term exposure to high temperatures, resulting in an effective minimization of microorganisms but also leads to nutritional and antioxidant losses. It was found that higher temperature negatively affects the quality parameters of watermelon and temperature above $78^{\circ} \mathrm{C}$ has an adverse effect on color change and aroma [19].

Some studies reported that levels of mono-cis forms of lycopene decrease with increasing heating time, suggesting that the rate of degradation of mono-cis lycopene is faster than the rate of its formation. In contrast, di-cis isomers of lycopene showed an increase during heating, probably due to the conversion of mono-cis lycopene. Di-cis lycopene levels increase during heat treatment, but their content decreases after prolonged exposure to heat. The largest losses of lycopene are recorded at temperatures around $150{ }^{\circ} \mathrm{C}$ [20].

Several bioavailability studies suggest that industrially processed tomato products are a better source of carotenoids than raw tomatoes. The content of lycopene in products processed in this way can be up to twice as high. Higher values of lycopene after heat treatment may be related to the extractability of lycopene, which increases significantly after heat treatment. Lycopene levels are also increased by mechanical homogenization, in which the protein complexes to which lycopene is bound are broken [11].

Heat treatment or homogenization of food improves the bioavailability of lycopene by breaking down the cell walls, resulting in a weakening of the bonds between lycopene and the tissue matrix and thus increases the available area for lycopene absorption. Due to its lipophilicity, an increase in absorbability is also achieved by the addition of fats in the heat treatment of lycopene-containing foods [8].

Lycopene trans- isomers are stable in the plant matrix, but upon disruption they are susceptible to heat-induced isomerization to cis isomers, which are better absorbed. The carotenoid profile of watermelon is similar to that of tomatoes. However, watermelon is not often heat-treated, which prevents cis-form isomerization [21]. Several studies suggest that the availability of lycopene from watermelon, which was not heat-treated, is the same as the availability of lycopene from heat-treated tomatoes. Unlike tomatoes, watermelon has larger cells with thinner cell walls, and lycopene, which is freely bound to the cell walls, can be released without heat treatment [22].

Many studies on the bioavailability of lycopene have focused on tomatoes and tomato products, which represent $80 \%$ of the lycopene ingested in the U.S. population. According to research, the concentration of lycopene in watermelon $(4868 \mu \mathrm{g} / 100 \mathrm{~g})$ is approximately $40 \%$ higher than the annual average of raw tomatoes $(3025 \mu \mathrm{g} / 100 \mathrm{~g})$. The content of carotenoids absorbed from plants is generally lower compared to food supplements containing carotenoids. Due to its chemical structure, lycopene is relatively stable, and its bioavailability is low, but the bioavailability of lycopene, such as $\beta$-carotene, increases with heating or homogenization [21]. 


\subsection{Lycopene Content}

In recent years, attention has been focused on carotenoids that serve as vitamin $\mathrm{A}$ provitamins in human body, primarily on $\alpha$ - and $\beta$-carotene and their effects on human health. Over time it was demonstrated that lycopene is a key phytochemical compound with highly beneficial effects on human health, mainly due to its antioxidant effect [5]. The first studies of the biological activity of lycopene were performed in 1959, when reduced mortality was found in laboratory mice after lycopene injection [23]. Lycopene is a non-provitamin carotenoid due to the absence of $\beta$-ionone ring, but it is still the strongest, naturally occurring antioxidant, which has 2 times higher antioxidant capacity than $\beta$-carotene [24].

\subsubsection{Lycopene Content Determined by HPLC}

A decrease in lycopene content was observed for all watermelon samples listed in Table 2 that were exposed to $40^{\circ} \mathrm{C}$. In the case of sample number 2, only a slight decrease was evident with a statistically insignificant difference compared to the control. This low difference can be explained by the short exposure time. In contrast, samples number 3 and 4 , which were exposed to the high temperature for a longer period, showed a decrease in lycopene with a statistically significant difference $(p<0.05)$ compared to the control. In samples number 5,6 , and 7 , exposed to a temperature of $70^{\circ} \mathrm{C}$, a decrease in lycopene was observed with a statistically significant difference $(p<0.05)$ compared to the unheated sample. The table also shows changes in lycopene values in samples exposed to $100{ }^{\circ} \mathrm{C}$. From the measured values, the degradation of lycopene was evident, increasing with increasing heating period. Samples number 8,9 , and 10 showed a decrease with a statistically significant difference $(p<0.05)$ that is consistent with the work of Yetenayet and Hosahalli (2015), reporting that lycopene degradation increased with increasing heating time [25]. The decrease in lycopene at $100{ }^{\circ} \mathrm{C}$ was also reported in the study examining the effect of heat treatment on the lycopene content of tomato puree [26]. Compared to the values from the present study, in the study conducted by Shi et al. (2003) the degradation of lycopene was not that significant with increasing heat treatment time, and it represented only losses from $0.15 \%$ to $3.47 \%$, but these results also show that lycopene degradation increases with the duration of heat treatment [26].

Table 2. Effect of sample heat treatment at $40,70,100{ }^{\circ} \mathrm{C}$ on the lycopene content of the watermelon determined spectrophotometrically and by HPLC.

\begin{tabular}{|c|c|c|c|}
\hline Sample & $\begin{array}{c}\text { LYCOPENE } \\
\text { HPLC }(\mathrm{mg} / \mathrm{kg})\end{array}$ & $\begin{array}{l}\text { LYCOPENE with Interference of } \\
\beta \text {-Carotene Pigments (mg/kg) }\end{array}$ & $\begin{array}{l}\text { LYCOPENE without Interference } \\
\text { from Other Pigments }(\mathrm{mg} / \mathrm{kg})\end{array}$ \\
\hline 1. Control Sample & $179.00 \pm 0.64^{\mathrm{a}}$ & $60.44 \pm 0.15^{a}$ & $56.94 \pm 4.37^{\mathrm{a}}$ \\
\hline 2. $40^{\circ} \mathrm{C}, 2 \mathrm{~min}$ & $176.59 \pm 2.72^{b a}$ & $62.42 \pm 0.39^{a}$ & $61.42 \pm 0.37^{b}$ \\
\hline 3. $40^{\circ} \mathrm{C}, 5 \mathrm{~min}$ & $123.91 \pm 1.52^{c}$ & $66.84 \pm 0.25^{c}$ & $65.45 \pm 0.20^{c}$ \\
\hline 4. $40{ }^{\circ} \mathrm{C}, 15 \mathrm{~min}$ & $155.12 \pm 1.21^{\mathrm{d}}$ & $55.61 \pm 0.10^{d}$ & $54.64 \pm 0.10^{d}$ \\
\hline 5. $70^{\circ} \mathrm{C}, 2 \mathrm{~min}$ & $88.72 \pm 0.36^{\mathrm{e}}$ & $44.94 \pm 0.05^{\mathrm{e}}$ & $44.21 \pm 0.06^{\mathrm{e}}$ \\
\hline 6. $70^{\circ} \mathrm{C}, 5 \mathrm{~min}$ & $151.63 \pm 0.89 \mathrm{fd}$ & $49.87 \pm 0.02^{\mathrm{f}}$ & $49.00 \pm 0.03^{f}$ \\
\hline 7. $70{ }^{\circ} \mathrm{C}, 15 \mathrm{~min}$ & $163.15 \pm 0.51 \mathrm{gb}$ & $43.31 \pm 1.20$ gdefi & $42.30 \pm 0.10$ gef \\
\hline 8. $100^{\circ} \mathrm{C}, 2 \mathrm{~min}$ & $152.07 \pm 0.15$ hd & $60.70 \pm 0.04^{\mathrm{a}}$ & $59.70 \pm 0.05$ hab \\
\hline 9. $100^{\circ} \mathrm{C}, 5 \mathrm{~min}$ & $129.90 \pm 0.29$ ic & $56.54 \pm 0.06^{\mathrm{i}}$ & $55.56 \pm 0.07^{\mathrm{i}}$ \\
\hline 10. $100^{\circ} \mathrm{C}, 15 \mathrm{~min}$ & $120.00 \pm 0.11^{j c}$ & $44.04 \pm 0.21$ je & $43.01 \pm 0.18^{\text {jef }}$ \\
\hline
\end{tabular}

Explanatory notes: Lowercase letters $(a-j)$ in the superscript indicate a statistically significant difference $(p<0.05)$ within one column; the same lowercase letters $(a-j)$ are indicating not found statistically significant difference $(p>0.05)$.

\subsubsection{Lycopene Content Determined by Spectrophotometry}

Furthermore, the lycopene content was determined by spectrophotometry. The middle part of the table shows the results of lycopene with interference with other pigments, namely $\beta$-carotene. Together with lycopene, some other pigments can be extracted into the upper non-polar phase when measured and can thus contribute to the measured 
absorbance at $503 \mathrm{~nm}$. The most significant interference is caused by $\beta$-carotene and based on its absorption spectrum, a few percent deviation in the determination of lycopene content can be expected [16].

The measured results show changes in the concentration of lycopene in samples number 2, 3, and 4, treated at a temperature of $40{ }^{\circ} \mathrm{C}$ for 2,5 , and $15 \mathrm{~min}$, respectively. Samples 2 and 3 showed an increase in lycopene content compared to the control sample. In the case of sample 3 , a statistically significant difference $(p<0.05)$ was evident compared to the control sample.

The concentration of lycopene increases after heat treatment, which may be associated with increased extractability after thermal pasteurization and mechanical homogenization, due to the disruption of protein complexes to which lycopene is bound [11]. Sample number 4 , exposed to $40{ }^{\circ} \mathrm{C}$ for $15 \mathrm{~min}$, showed a decrease with a statistically significant difference $(p<0.05)$ compared to the unheated sample (control sample). This phenomenon may be related to the duration of heat treatment. It was reported that the rate of lycopene degradation increases with increasing temperature and time [25].

In samples number 5, 6, and 7, which were exposed to temperature of $70^{\circ} \mathrm{C}$, a decrease in lycopene was observed with a statistically significant difference $(p<0.05)$ compared to the control samples. The highest decrease was recorded for samples that were exposed to heat for the longest time.

In samples number 9 and 10, which were exposed to the highest temperature of $100{ }^{\circ} \mathrm{C}$, the degradation of lycopene was evident with increasing duration of temperature exposure with a statistically significant difference $(p<0.05)$ compared to the control sample. Oppositely, in sample number 8, a slight increase in lycopene was observed with a statistically insignificant difference compared to the control samples, due to the short heating time.

The lycopene values measured spectrophotometrically in the watermelon samples are comparable to those reported by Perkins-Veazie et al. (2006) [27]. In their study, the authors focused on measuring the lycopene content in various commercially available watermelon varieties, where the average values ranged from 50 to $70 \mathrm{mg} / \mathrm{kg}$ fresh weight. As demonstrated by the previous study, the content of lycopene in watermelon also varies depending on the variety and growing conditions [28].

The effect of heat treatment on the lycopene content of watermelon juice was also investigated in the study conducted by Yetenayet and Hosahalli (2015), where samples of watermelon juice were exposed to temperatures of 70,80 and $90{ }^{\circ} \mathrm{C}$ [25]. Heat treatment at $70{ }^{\circ} \mathrm{C}$ was performed for 15,25 , and $35 \mathrm{~min}$. For heat treatment at $80{ }^{\circ} \mathrm{C}$, heat treatment times were 10, 20 and $30 \mathrm{~min}$, and the effect of $90^{\circ} \mathrm{C}$ was examined for 5, 10, and $15 \mathrm{~min}$. Slight degradation of lycopene was found in all samples, and it increased with increasing temperature and exposure time; however, the rate of degradation was not significant. The highest losses of lycopene were recorded at $90{ }^{\circ} \mathrm{C}$ for $15 \mathrm{~min}$, where a loss of $4.2 \%$ was measured. Losses of lycopene at $70{ }^{\circ} \mathrm{C}$ for the same exposure time of $15 \mathrm{~min}$ represented only $0.8 \%$ of the total lycopene content. The previous study observed that decrease in lycopene values is thus evident with increasing temperature and exposure time from $70{ }^{\circ} \mathrm{C}$ [25].

The right part of Table 2 shows more accurate values of lycopene after heat treatment at temperatures of 40,70 and $100{ }^{\circ} \mathrm{C}$ with exposure times of 2, 5, and $15 \mathrm{~min}$, without interference by other pigments. In contrast, samples number 2 and 3, which were exposed to the temperature of $40{ }^{\circ} \mathrm{C}$, showed an increase in lycopene content with a statistically significant difference $(p<0.05)$ compared to the control. A decrease with a statistically significant difference $(p<0.05)$ can be observed for the sample that has been exposed to this temperature for the longest period compared to the unheated sample, which may be related to the duration of the heat treatment. Samples number 5, 6, and 7 that were exposed to $70{ }^{\circ} \mathrm{C}$, showed a decrease in lycopene with a statistically significant difference $(p<0.05)$ compared to the unheated control sample. The highest loss was observed for the sample that was heat-treated for the longest period. Samples number 9 and 10 that were exposed to the temperature of $100{ }^{\circ} \mathrm{C}$, the degradation of lycopene was evident with increasing 
exposure duration with a statistically significant $(p<0.05)$ difference compared to control samples. In the case of sample number 8, on the other hand, a slight increase in lycopene content was observed with a statistically insignificant difference from the control, which can be explained by a shorter heating exposure time.

In the study conducted by Makroo et al. (2017), the lycopene content was also monitored spectrophotometrically, where the lycopene content was measured in samples of fresh watermelon juice at $63.47 \pm 0.48 \mathrm{mg} / \mathrm{mL}$, similar results are reported by Oms-Oliu et al. (2009) [29,30]. In samples of watermelon juice heat-treated at $90{ }^{\circ} \mathrm{C}$ for $15,30,45$, and $60 \mathrm{~s}$, the researchers recorded a slight decrease. Sharma et al. (2008), Kong et al. (2010) also stated that higher temperatures can lead to degradation of the lycopene content in watermelon juice [31-33]. It was reported that changes in lycopene content can be caused by thermal destruction and oxidation, leading to the formation of products such as acetone, methyl-heptenone, laevulinic aldehyde, and glyoxal [34].

\subsection{Antioxidant Capacity}

According to the available literature, antioxidant activity is defined as the reduction of oxidation of proteins, lipids, DNA, or other molecules, which occurs by blocking the propagation phase in oxidative chain reactions. Primary antioxidants directly scavenge free radicals, while secondary antioxidants indirectly prevent free radical formation through the Fenton reaction [35]. The following table shows the measured antioxidant activity values that were determined by different methods.

\subsubsection{Antioxidant Capacity Determined by the FRAP Method}

The first method used to determine the antioxidant capacity was the FRAP method. The values of the heat-treated samples at $40{ }^{\circ} \mathrm{C}$ were measured and are shown in Table 3 , where they indicate an increasing tendency of antioxidant activity with increasing duration of temperature exposure. However, in samples number 2 and 3, a slight decrease of antioxidant activity of about $10-19 \%$ was recorded in comparison with the control. Sample number 4 that was exposed to the temperature of $40{ }^{\circ} \mathrm{C}$ for $15 \mathrm{~min}$, showed an increase in antioxidant activity with a statistically significant $(p<0.05)$ difference of $66 \%$. Samples exposed to $70{ }^{\circ} \mathrm{C}$ showed a higher decrease in antioxidant activity compared to samples exposed to $40{ }^{\circ} \mathrm{C}$. Sample number 6 showed a decrease with a statistically significant difference $(p<0.05)$ in contrast to the control.

The influence of conventionally used pasteurization methods on the antioxidant activity of watermelon juice by the FRAP method was also investigated in the study where the samples were treated at $75^{\circ} \mathrm{C}$ for $3 \mathrm{~min}$ [36]. The results of the study showed a decrease of $25 \%$ in the reduction of iron ions compared to the unheated sample, which is comparable to the result of the sample number 5 that was exposed to a temperature of $70^{\circ} \mathrm{C}$ for $2 \mathrm{~min}$. This sample showed $27 \%$ decrease in the antioxidant activity. A decrease in the values of antioxidant activity was also recorded for samples number 8, 9, and 10 that were exposed to the highest temperature of $100^{\circ} \mathrm{C}$. For samples number 8 and 9 , a decrease of about 49-60\% was recorded.

\subsubsection{Determination of Total Polyphenols Content}

Another measured parameter was phenolic compounds which are secondary metabolites in plants, whose task is to develop the color and taste of fruit juices [34]. They also act as important antioxidants that are divided into phenolic acids, flavonoids, lignans, and stilbenes [37]. In their study, Makroo et al. (2017) state that the content of polyphenols in fresh watermelon juice is around $11.27 \pm 0.04 \mathrm{mg}$ gallic acid equivalent (GAE)/100 mL, and similar results are reported in the previous studies too $[29,34]$. 
Table 3. Effect of sample heat treatment at $40,70,100{ }^{\circ} \mathrm{C}$ on the value of antioxidant activity in watermelon determined by FRAP, NOS, ABTS methods, and total polyphenols content.

\begin{tabular}{ccccc}
\hline Sample & $\begin{array}{c}\text { FRAP } \\
(\mu \mathrm{mol} \text { (Trolox)/g) }\end{array}$ & $\begin{array}{c}\text { Polyphenols Content } \\
(\text { Gallic Acid mg/g) }\end{array}$ & NOS (\%) & $\begin{array}{c}\text { ABTS ( } \mu \text { mol } \\
\text { (Trolox)/g }\end{array}$ \\
\hline 1. Control Sample & $0.41 \pm 0.05^{\mathrm{a}}$ & $0.47 \pm 0.02^{\mathrm{a}}$ & $13.06 \pm 4.17$ & $2.25 \pm 0.04^{\mathrm{a}}$ \\
$2.40^{\circ} \mathrm{C}, 2 \mathrm{~min}$ & $0.33 \pm 0.08^{\mathrm{ae}}$ & $1.14 \pm 0.01^{\mathrm{bc}}$ & $14.44 \pm 0.47^{\mathrm{ag}}$ & $2.36 \pm 0.11^{\mathrm{a}}$ \\
$3.40^{\circ} \mathrm{C}, 5 \mathrm{~min}$ & $0.37 \pm 0.11^{\mathrm{a}}$ & $1.12 \pm 0.01^{\mathrm{cb}}$ & $15.10 \pm 0.21^{\mathrm{ae}}$ & $2.52 \pm 0.04^{\mathrm{ac}}$ \\
$4.40^{\circ} \mathrm{C}, 15 \mathrm{~min}$ & $0.68 \pm 0.13^{\mathrm{b}}$ & $1.38 \pm 0.01^{\mathrm{d}}$ & $15.33 \pm 0.26^{\mathrm{a}}$ & $2.61 \pm 0.10^{\mathrm{ad}}$ \\
$5.70^{\circ} \mathrm{C}, 2 \mathrm{~min}$ & $0.30 \pm 0.07^{\mathrm{ae}}$ & $1.04 \pm 0.01^{\mathrm{e}}$ & $12.58 \pm 0.24$ & $2.72 \pm 0.03^{\mathrm{ae}}$ \\
$6.70^{\circ} \mathrm{C}, 5 \mathrm{~min}$ & $0.14 \pm 0.03^{\mathrm{ce}}$ & $0.90 \pm 0.01^{\mathrm{f}}$ & $14.26 \pm 0.13^{\mathrm{ag} j}$ & $2.91 \pm 0.08^{\mathrm{fcde}}$ \\
$7.70^{\circ} \mathrm{C}, 15 \mathrm{~min}$ & $0.19 \pm 0.08^{\mathrm{ae}}$ & $0.54 \pm 0.01^{\mathrm{g}}$ & $11.76 \pm 0.26^{\mathrm{gb}}$ & $2.91 \pm 0.15 \mathrm{gcde}$ \\
$8.100^{\circ} \mathrm{C}, 2 \mathrm{~min}$ & $0.21 \pm 0.01^{\mathrm{ae}}$ & $0.99 \pm 0.01^{\mathrm{h}}$ & $9.30 \pm 0.24^{\mathrm{b}}$ & $3.34 \pm 0.13^{\mathrm{hfg}}$ \\
$9.100^{\circ} \mathrm{C}, 5 \mathrm{~min}$ & $0.16 \pm 0.06^{\mathrm{de}}$ & $0.87 \pm 0.01^{\mathrm{i}}$ & $7.69 \pm 0.12^{\mathrm{b}}$ & $3.41 \pm 0.02^{\mathrm{ihg}}$ \\
$10.100^{\circ} \mathrm{C}, 15 \mathrm{~min}$ & $0.38 \pm 0.04^{\mathrm{a}}$ & $1.17 \pm 0.01^{\mathrm{j}}$ & $10.62 \pm 0.29^{\mathrm{bj}}$ & $3.49 \pm 0.11^{\mathrm{jhi}}$ \\
\hline
\end{tabular}

Explanatory notes: Lowercase letters $(\mathrm{a}-\mathrm{j})$ in the superscript indicate a statistically significant difference $(p<0.05)$ within one column; the same lowercase letters $(\mathrm{a}-\mathrm{j})$ are indicating not found statistically significant difference $(p>0.05)$.

The results of the determination of the total polyphenols content in the watermelon samples are given in Table 3. All samples showed an increase in polyphenols content with a statistically significant difference $(p<0.05)$ compared to control samples and a statistically significant difference $(p<0.05)$ between almost all samples, except for samples number 2 and 3 , between which no statistical significance was found.

In samples number 2, 3, and 4 that were exposed to $40^{\circ} \mathrm{C}$ for 2,5 , and $15 \mathrm{~min}$ respectively, more than twice the amount (178-236\%) of polyphenols was measured compared to the control samples with a statistically significant difference $(p<0.05)$.

All samples exposed to $70^{\circ} \mathrm{C}$ showed an increase in polyphenols with a statistically significant difference $(p<0.05)$, but these values were lower than those exposed to $40{ }^{\circ} \mathrm{C}$. At a temperature of $70^{\circ} \mathrm{C}$, the highest increase in polyphenols was recorded in sample number 5. For samples number 5,6 , and 7 , there was an increase with a statistically significant difference $(p<0.05)$ compared to control samples with increasing exposure time. These samples showed statistical significance $(p<0.05)$ with all samples.

Similar results were obtained by the team of authors led by Dewanto et al. (2002) who investigated the effect of $88^{\circ} \mathrm{C}$ temperature with exposure times of 2,15 , and $30 \mathrm{~min}$ on the total polyphenols content of tomatoes [38]. As in the case of the present study, an increase in polyphenols was observed in all samples exposed to different temperatures with the same decreasing tendency with increasing heat exposure time. The increase in the content of polyphenols with a statistically significant difference $(p<0.05)$ compared to control samples was also measured at a temperature of $100{ }^{\circ} \mathrm{C}$ in samples number 8,9 , and 10 . The effect of heat treatment on the total polyphenols content was also investigated by Kim et al. (2008), reporting that heating watermelon at $150{ }^{\circ} \mathrm{C}$ increased the total polyphenol content from 0.07 to $2.60 \mathrm{mg} / \mathrm{g}$ [39]. Previous studies demonstrated that heat treatment converts insoluble phenolic compounds to soluble forms, allowing phenolic compounds in plants to be released by the heat treatment process $[40,41]$.

\subsubsection{Antioxidant Capacity Determined by the NOS Method}

Table 3 also shows the measured values of antioxidant activity in watermelon samples at $40,70,100{ }^{\circ} \mathrm{C}$ determined by the NOS method. In samples number 2,3 , and 4 , the values of antioxidant activity were measured with a statistically insignificant difference compared to control samples. The evaluation of the results revealed an increasing trend of the measured values depending on the duration of exposure to high temperatures. This phenomenon could be due to higher amounts of polyphenols and lycopene that were measured when treated at $40^{\circ} \mathrm{C}$.

A slight increase in antioxidant activity with a statistically insignificant difference compared to the unheated samples was also recorded in the case of sample number 6 that 
was exposed to temperature of $70^{\circ} \mathrm{C}$ for $5 \mathrm{~min}$. In contrast, samples 5 and 7 showed a slight decrease in antioxidant activity with a statistically insignificant difference compared to control samples. This decrease can be explained by the degradation of lycopene, observed during the heat treatment at $70{ }^{\circ} \mathrm{C}$.

A decrease in antioxidant activity was also observed in samples number 8, 9, and 10 that were exposed to a temperature of $100{ }^{\circ} \mathrm{C}$. For samples number 8 and 10 , this decrease was recorded with a statistically insignificant difference compared to the unheated sample. The decrease in antioxidant activity can be explained by the degradation of lycopene, observed at $100{ }^{\circ} \mathrm{C}$.

\subsubsection{Antioxidant Capacity Determined by the ABTS Method}

The ABTS method was also used to determine antioxidant activity. In comparison with the unheated control sample number 1 , the measured values demonstrated a slight increase of antioxidant activity in all samples of watermelon that were exposed to a temperature of $40^{\circ} \mathrm{C}$, and it gradually increased with the duration of heat exposure. For all samples exposed to $40^{\circ} \mathrm{C}$ for 2, 5, and $15 \mathrm{~min}$ (samples number 2, 3, and 4), this increase was recorded with a statistically insignificant difference. The increase in antioxidant activity determined by the ABTS method after heat treatment, can be explained by the increased values of polyphenols or lycopene, which were measured in all samples exposed to this temperature. A gradual increase in the values of antioxidant activity depending on the duration of the heat treatment on the watermelon samples, was also observed in the samples that were exposed to a temperature of $70^{\circ} \mathrm{C}$. Sample number 5 showed an increase in antioxidant activity with a statistically insignificant difference compared to the control, while samples number 6 and 7 showed an increase with a statistically significant difference $(p>0.05)$ compared to the control sample. The increasing ability of the measured sample to quench the ABTS $\bullet+$ cation-radical can probably be attributed to polyphenols due to their increased content, which was measured even at $70^{\circ} \mathrm{C}$, while lycopene already showed degradation at this temperature. The gradual increase of antioxidant activity with increasing duration of temperature exposure was also evident in the following series of samples which were exposed to the highest temperature of $100{ }^{\circ} \mathrm{C}$. An increase in antioxidant activity was observed in all samples 8, 9, and 10 with a statistically significant difference $(p>0.05)$ compared to the control [37].

Many antioxidant compounds in plants are present in the covalently bonded form of compounds with insoluble polymers [42]. The effect of heat treatment on these bound forms of antioxidants disrupts the cell wall and therefore causes the subsequent release of antioxidant compounds from the insoluble form.

The effect of heat on the activity of scavenging free radicals in watermelon by the ABTS method was also investigated in a study by Kim et al. (2014) in which they state that the values of antioxidant activity also increased with increasing temperature and time of exposure [39].

\subsection{Organic Acids}

The most common organic acids in watermelon include malic acid, citric acid, and oxalic acid, of which malic acid predominates [43]. Table 4 shows the resulting values of organic acids content with statistical evaluation between individual samples.

Table 4 shows the measured values of the above-mentioned organic acids after applying temperatures of 40,70 , and $100{ }^{\circ} \mathrm{C}$ to watermelon samples for 2, 5, and 15 min. For the first series of samples which were exposed to a temperature of $40{ }^{\circ} \mathrm{C}$, a decrease in the monitored parameters was measured. A decrease in oxalic acid was observed without a statistically significant difference $(p<0.05)$. For malic acid, a decrease in values was recorded, which grew with increasing duration of heat exposure. For samples in number 2, 3 , and 4 , there was a decrease with a statistically insignificant difference $(p<0.05)$ compared to the control. In the last determined organic acid, which was the citric acid, a decrease of 
values was also recorded with a statistically insignificant difference $(p<0.05)$ in all samples compared to the control.

Table 4. Effect of sample heat treatment at $40,70,100{ }^{\circ} \mathrm{C}$ on the content of organic acids by the HPLC method.

\begin{tabular}{cccc}
\hline Sample & Oxalic Acid mg/kg & Malic Acid mg/kg & Citric Acid mg/kg \\
\hline 1. control sample & $4.89 \pm 0.01$ & $166.62 \pm 20.91$ & $85.80 \pm 0.05$ \\
$2.40^{\circ} \mathrm{C}, 2 \mathrm{~min}$ & $3.76 \pm 0.01^{\mathrm{a}}$ & $162.51 \pm 0.46^{\mathrm{a}}$ & $78.00 \pm 0.06^{\mathrm{a}}$ \\
$3.40^{\circ} \mathrm{C}, 5 \mathrm{~min}$ & $1.78 \pm 0.01^{\mathrm{b}}$ & $111.85 \pm 0.30^{\mathrm{b}}$ & $35.30 \pm 0.22^{\mathrm{b}}$ \\
$4.40^{\circ} \mathrm{C}, 15 \mathrm{~min}$ & $2.71 \pm 0.01^{\mathrm{c}}$ & $53.11 \pm 0.11^{\mathrm{c}}$ & $49.81^{\mathrm{d}} \pm 0.31^{\mathrm{c}}$ \\
$5.70^{\circ} \mathrm{C}, 2 \mathrm{~min}$ & $3.08 \pm 0.08^{\mathrm{dc}}$ & $128.39 \pm 5.21^{\mathrm{db}}$ & $68.16 \pm 0.10^{\mathrm{d}}$ \\
$6.70^{\circ} \mathrm{C}, 5 \mathrm{~min}$ & $2.21 \pm 0.01^{\mathrm{e}}$ & $130.95 \pm 0.11^{\mathrm{ed}}$ & $43.85 \pm 0.01^{\mathrm{e}}$ \\
$7.70^{\circ} \mathrm{C}, 15 \mathrm{~min}$ & $5.06 \pm 0.01^{\mathrm{f}}$ & $77.99 \pm 0.12^{\mathrm{f}}$ & $63.23 \pm 0.60^{\mathrm{f}}$ \\
$8.100^{\circ} \mathrm{C}, 2 \mathrm{~min}$ & $6.32 \pm 0.01^{\mathrm{g}}$ & $79.64 \pm 0.01^{\mathrm{g}}$ & $63.14 \pm 0.01 \mathrm{gf}$ \\
$9.100^{\circ} \mathrm{C}, 5 \mathrm{~min}$ & $5.39 \pm 0.01^{\mathrm{hg}}$ & $70.30 \pm 0.01^{\mathrm{hg}}$ & $58.71 \pm 0.01^{\mathrm{hg}}$ \\
$10.100^{\circ} \mathrm{C}, 15 \mathrm{~min}$ & $4.24 \pm 0.01^{\mathrm{ig}}$ & $57.08 \pm 0.01^{\mathrm{ig}}$ & $37.58 \pm 0.01^{\mathrm{ig}}$ \\
\hline
\end{tabular}

Explanatory notes: Lowercase letters $(a-i)$ in the superscript indicate a statistically significant difference $(p<0.05)$ within one column; the same lowercase letters $(\mathrm{a}-\mathrm{j})$ are indicating not found statistically significant difference $(p>0.05)$.

At $70{ }^{\circ} \mathrm{C}$, a decrease in organic acids levels was observed in almost all samples, except for sample number 7 , where an increase in oxalic acid was recorded. In the remaining samples number 5 and 6 , on the other hand, a decrease in oxalic acid was recorded without a statistically significant difference $(p<0.05)$ compared to the control. With a statistically insignificant difference $(p>0.05)$ from control samples, a decrease in citric acid was also observed in all samples.

In samples exposed to $100{ }^{\circ} \mathrm{C}$, it was possible to observe an increase in oxalic acid in samples number 8 and 9 and a slight decrease in sample number 10 which was exposed to this temperature the longest. No statistically significant difference was found in these samples compared to the control sample. A decrease in oxalic acid was observed in all samples without a statistically significant difference $(p<0.05)$. The degradation of malic acid in this case increased with increasing heating time. A similar declining trend with increasing heating duration was also observed for citric acid. A decrease was observed in all these samples with a statistically insignificant difference $(p<0.05)$.

The presence of organic acids in watermelon was also examined in the study by Gölükcü and Tokgöz (2018) who reported comparable levels of malic acid with values ranging from $67.50 \mathrm{mg} / \mathrm{kg}$ to $151.50 \mathrm{mg} / \mathrm{kg}$ with respect to different varieties of watermelon [44]. The highest values were recorded for citric acid with values from $143.75 \mathrm{mg} / \mathrm{kg}$ to $190.75 \mathrm{mg} / \mathrm{kg}$, which is up to twice the values in the control of the present study. Other acids were also determined in watermelon samples: tartaric acid and acetic acid [44].

The overall differences between samples of watermelon that included all conducted analysis are shown in Figure 1. It can be seen, though not fully unambiguously, that control samples (the samples of watermelon without heat treatment) are the closest to the samples treated at lower temperatures during shorter period. 


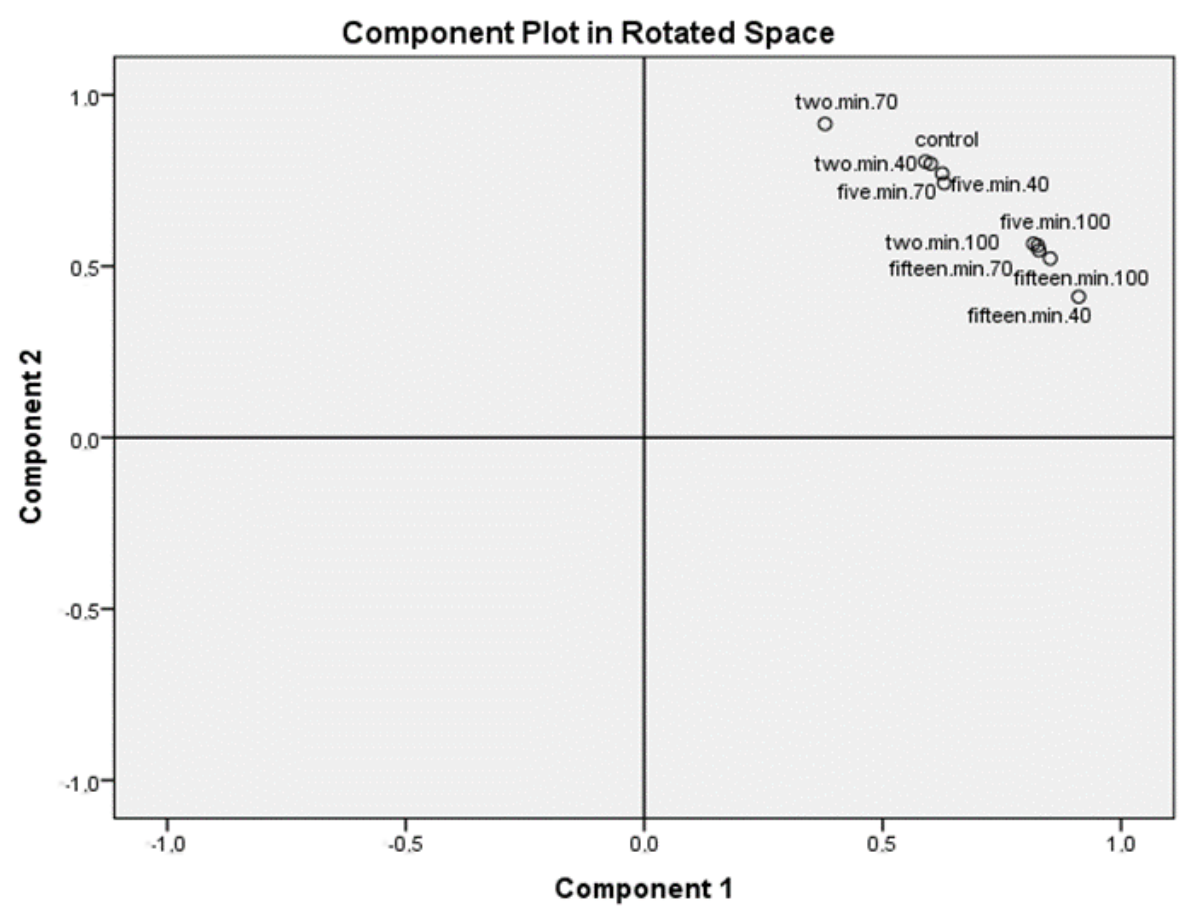

Figure 1. Principal component analysis for all analyses obtained for analyzed samples.

\section{Conclusions}

The work monitored the degree of thermostability of bioactive compounds in watermelon processed by different temperatures exposures. The study emphasized differences between results obtained by spectrophotometric and chromatographic methods, though concentrations of bioactive compounds were not increasing and decreasing according to the certain pattern. It was observed that temperatures over $70^{\circ} \mathrm{C}$ affected more significantly $(p<0.05)$ contents of lycopene, polyphenols, same as antioxidant capacity. The obtained results can serve as good indicators for watermelon processing and its inclusion in different food commodities, though results are valuable information for further experiments and research. Since, the popularity of fortified products among consumers has been growing significantly recently these results represent important findings for the development of products containing watermelon that can serve as the fortification element due to the high content of bioactive compounds, especially lycopene.

Author Contributions: Conceptualization, B.T., D.D. and H.K.M.; methodology, S.D., T.P., K.T., D.D.; software, D.D.; validation, D.D., B.T. and S.D.; formal analysis, T.P., K.T., S.D.; investigation, D.D., T.P.; resources, B.T.; data curation, D.D., S.D.; writing-original draft preparation, D.D., H.K.M., B.T.; writing-review and editing, B.T., H.K.M., D.D.; visualization, H.K.M.; supervision, B.T., D.D.; project administration, B.T.; funding acquisition, B.T. All authors have read and agreed to the published version of the manuscript.

Funding: Supported by funds from the Ministry of Education, Youth and Sports for institutional support of long-term conceptual development of research organizations.

Institutional Review Board Statement: Not applicable.

Informed Consent Statement: Not applicable.

Data Availability Statement: Not applicable.

Conflicts of Interest: The authors declare no conflict of interest. 


\section{References}

1. Naz, A.; Sadiq Butt, M.; Pasha, I.; Nawaz, H. Antioxidant indices of watermelon juice and lycopene extract. Pak. J. Nutr. 2013, 12, 255-260. [CrossRef]

2. Andonova, L.; Georgieva, M.; Zlatkov, A. Free radicals, oxidative stres, and diseases associated with them. Pharmacia 2015, 62, 26-39.

3. Gill, S.S.; Tuteja, N. Reactive oxygen species and antioxidant machinery in abiotic stress tolerance in crop plants. Plant Physiol. Biochem. 2010, 48, 909-930. [CrossRef]

4. Sindhi, V.; Gupta, V.; Sharma, K.; Bhatnagar, S.; Kumari, R.; Dhaka, N. Potential applications of antioxidants-A review. J. Pharm. Res. 2013, 7, 828-835. [CrossRef]

5. Park, H.; Kim, Y.J.; Shin, Y. Estimation of daily intake of lycopene, antioxidant contents and activities from tomatoes, watermelons, and their processed products in Korea. Appl. Biol. Chem. 2020, 63, 50. [CrossRef]

6. Choudhary, B.R.; Haldhar, S.M.; Maheshwari, S.K.; Bhargava, R.; Sharma, S.K. Phytochemicals and antioxidants in watermelon (Citrullus lanatus) genotypes under hot arid region. Indian J. Agric. Sci. 2015, 85, 414-421.

7. Naz, A.; Butt, M.S.; Sultan, M.T.; Qayyum, M.M.N.; Niaz, R.S. Watermelon lycopene and allied health claims. Excli J. 2014, 13, 650-666.

8. Xianquan, S.; Shi, J.; Kakuda, Y.; Yueming, J. Stability of lycopene during food processing and storage. J. Med. Food 2005, 8, 413-422. [CrossRef] [PubMed]

9. Nagarajan, J.; Ramanan, R.N.; Raghunandan, M.E.; Galanakis, C.M.; Krishnamurthy, N.P. Chapter 8-Carotenoids. In Nutraceutical and Functional Food Components; Galanakis, C.M., Ed.; Academic Press: Cambridge, MA, USA, 2017; pp. 259-296, ISBN 978-0-12805257-0.

10. Clinton, S.K.; Emenhiser, C.; Schwartz, S.J.; Bostwick, D.G.; Williams, A.W.; Moore, B.J.; Erdman, J.W.J. cis-trans lycopene isomers, carotenoids, and retinol in the human prostate. Cancer Epidemiol. Prev. Biomark. 1996, 5, 823-833.

11. Evoli, L.; Lombardi-Boccia, G.; Lucarini, M. Influence of Heat Treatments on Carotenoid Content of Cherry Tomatoes. Foods 2013, 2, 352-363. [CrossRef]

12. Paulová, H.; Bochořákováa, H.; Táborská, E. Metody stanovení antioxidační aktivity př́rodních látek in vitro. Chem. List. 2004, 98, 174-179.

13. Thaipong, K.; Boonprakob, U.; Crosby, K.; Cisneros-Zevallos, L.; Hawkins Byrne, D. Comparison of ABTS, DPPH, FRAP, and ORAC assays for estimating antioxidant activity from guava fruit extracts. J. Food Compos. Anal. 2006, 19, 669-675. [CrossRef]

14. Boora, F.; Chirisa, E.; Mukanganyama, S. Evaluation of Nitrite Radical Scavenging Properties of Selected Zimbabwean Plant Extracts and Their Phytoconstituents. J. Food Process. 2014, 2014, 1-7. [CrossRef]

15. Tomadoni, B.; Cassani, L.; Ponce, A.; Moreira, M.R.; Agüero, M.V. Optimization of ultrasound, vanillin and pomegranate extract treatment for shelf-stable unpasteurized strawberry juice. Lwt-Food Sci. Technol. 2016, 72, 475-484. [CrossRef]

16. Anthon, G.; Barrett, D.M. Standardization of a rapid spectrophotometric method for lycopene analysis. Acta Hortic. 2007, 758, 111-128. [CrossRef]

17. Akagić, A.; Vranac, A.; Gaši, F.; Drkenda, P.; Spaho, N.; Oručević Žuljević, S.; Kurtović, M.; Musić, O.; Murtić, S.; Hudina, M. Sugars, acids and polyphenols profile of commercial and traditional apple cultivars for processing. Acta Agric. Slov. 2019, 113, 239-250. [CrossRef]

18. Nayik, G.A. Antioxidants in Fruits: Properties and Health Benefits; Springer Nature: London, UK, 2020; pp. 333-364, ISBN 9789811572845.

19. Maoto, M.M.; Beswa, D.; Jideani, A.I.O. Watermelon as a potential fruit snack. Int. J. Food Prop. 2019, 22, 355-370. [CrossRef]

20. Lee, M.T.; Chen, B.H. Stability of lycopene during heating and illumination in a model system. Food Chem. 2002, 78, 425-432. [CrossRef]

21. Edwards, A.J.; Vinyard, B.T.; Wiley, E.R.; Brown, E.D.; Collins, J.K.; Perkins-veazie, P.; Baker, R.A.; Clevidence, B.A. Human Nutrition and Metabolism of Lycopene and b-Carotene in Humans. J. Nutr. 2003, 133, 1043-1050. [CrossRef]

22. Perkins-Veazie, P.; Collins, J.K.; Clevidence, B.; Wu, G. Watermelons and health. Acta Hortic. 2007, 731, 121-127. [CrossRef]

23. Stahl, W.; Sies, H. Lycopene: A biologically important carotenoid for humans? Arch. Biochem. Biophys. 1996, 336, 1-9. [CrossRef]

24. Mendelová, A.; Andrejiová, A.; Lišková, M.; Kozelová, D.; Mareček, J. Analysis of Carotenoids and Lycopene in Tomato (Lycopersicon Esculentum Mill.) and Their Retention in Tomato Juice. Potravinarstvo 2012, 6, 36-38. [CrossRef]

25. Yetenayet, B.T.; Hosahalli, S.R. Temperature and high pressure stability of lycopene and vitamin C of watermelon Juice. Afr. J. Food Sci. 2015, 9, 351-358. [CrossRef]

26. Shi, J.; Le Maguer, M.; Bryan, M.; Kakuda, Y. Kinetics of lycopene degradation in tomato puree by heat and light irradiation. J. Food Process Eng. 2003, 25, 485-498. [CrossRef]

27. Perkins-Veazie, P.; Collins, J.K.; Davis, A.R.; Roberts, W. Carotenoid content of 50 watermelon cultivars. J. Agric. Food Chem. 2006, 54, 2593-2597. [CrossRef]

28. Fish, W.W.; Davis, A.R. The effects of frozen storage conditions on lycopene stability in watermelon tissue. J. Agric. Food Chem. 2003, 51, 3582-3585. [CrossRef]

29. Makroo, H.A.; Saxena, J.; Rastogi, N.K.; Srivastava, B. Ohmic heating assisted polyphenol oxidase inactivation of watermelon juice: Effects of the treatment on $\mathrm{pH}$, lycopene, total phenolic content, and color of the juice. J. Food Process. Preserv. 2017, 41, 6. [CrossRef] 
30. Oms-Oliu, G.; Odriozola-Serrano, I.; Soliva-Fortuny, R.; Martin-Belloso, O. Effects of high-intensity pulsed electric field processing conditions on lycopene, vitamin C and antioxidant capacity of watermelon juice. Food Chem. 2009, 115, 1312-1319. [CrossRef]

31. Kong, K.W.; Ismail, A.; Tan, C.P.; Rajab, N.F. Optimization of oven drying conditions for lycopene content and lipophilic antioxidant capacity in a by-product of the pink guava puree industry using response surface methodology. Lwt-Food Sci. Technol. 2010, 43, 729-735. [CrossRef]

32. Kong, K.W.; Khoo, H.E.; Prasad, K.N.; Ismail, A.; Tan, C.P.; Rajab, N.F. Revealing the power of the natural red pigment lycopene. Molecules 2010, 15, 959-987. [CrossRef] [PubMed]

33. Sharma, R.; Kaur, D.; Oberoi, D.P.S.; Sogi, D.S. Thermal degradation kinetics of pigments and visual color in watermelon juice. Int. J. Food Prop. 2008, 11, 439-449. [CrossRef]

34. Rawson, A.; Tiwari, B.K.; Patras, A.; Brunton, N.; Brennan, C.; Cullen, P.J.; O’Donnell, C. Effect of thermosonication on bioactive compounds in watermelon juice. Food Res. Int. 2011, 44, 1168-1173. [CrossRef]

35. Huang, D.J.; Ou, B.X.; Prior, R.L. The chemistry behind antioxidant capacity assays. J. Agric. Food Chem. 2005, 53, 1841-1856. [CrossRef] [PubMed]

36. Saikia, S.; Mahnot, N.K.; Mahanta, C.L. A comparative study on the effect of conventional thermal pasteurisation, microwave and ultrasound treatments on the antioxidant activity of five fruit juices. Food Sci. Technol. Int. 2016, 22, 288-301. [CrossRef] [PubMed]

37. Manivannan, A.; Lee, E.-S.; Han, K.; Lee, H.-E.; Kim, D.-S. Versatile Nutraceutical Potentials of Watermelon-A Modest Fruit Loaded with Pharmaceutically Valuable Phytochemicals. Molecules 2020, 25, 5258. [CrossRef]

38. Dewanto, V.; Wu, X.; Adom, K.K.; Liu, R.H. Thermal Processing Enhances the Nutritional Value of Tomatoes by Increasing Total Antioxidant Activity. J. Agric. Food Chem. 2002, 50, 3010-3014. [CrossRef]

39. Kim, S.J.; Matsushita, Y.; Fukushima, K.; Aoki, D.; Yagami, S.; Yuk, H.G.; Lee, S.C. Antioxidant activity of a hydrothermal extract from watermelons. Lwt-Food Sci. Technol. 2014, 59, 361-368. [CrossRef]

40. Jeong, S.M.; Kim, S.Y.; Kim, D.R.; Jo, S.C.; Nam, K.C.; Ahn, D.U.; Lee, S.C. Effect of heat treatment on the antioxidant activity of extracts from citrus peels. J. Agric. Food Chem. 2004, 52, 3389-3393. [CrossRef]

41. Kim, S.Y.; Jeong, S.M.; Park, W.P.; Nam, K.C.; Ahn, D.U.; Lee, S.C. Effect of heating conditions of grape seeds on the antioxidant activity of grape seed extracts. Food Chem. 2006, 97, 472-479. [CrossRef]

42. Choi, Y.; Lee, S.M.; Chun, J.; Lee, H.B.; Lee, J. Influence of heat treatment on the antioxidant activities and polyphenolic compounds of Shiitake (Lentinus edodes) mushroom. Food Chem. 2006, 99, 381-387. [CrossRef]

43. Muhammad Jawad, U.; Gao, L.; Gebremeskel, H.; Safdar, L.B.; Yuan, P.; Zhao, S.; Xuqiang, L.; Nan, H.; Hongju, Z.; Liu, W. Expression pattern of sugars and organic acids regulatory genes during watermelon fruit development. Sci. Hortic. (Amst.) 2020, 265, 109102. [CrossRef]

44. Gölükcu, M.; Tokgöz, H. Variation in Sugar, Organic Acid and Volatile Flavor Compounds of Watermelon (Citrullus lanatus) Grafted on Different Rootstocks at Different Harvest Time. Akad. Gida 2018, 16, 381-386. 